\title{
Contrasting Features of the July 2018 Heavy Rainfall Event and the 2017 Northern Kyushu Rainfall Event in Japan
}

\author{
Hiroki TSUJI, Chie YOKOYAMA, and Yukari N. TAKAYABU \\ Atmosphere and Ocean Research Institute, The University of Tokyo, Kashiwa, Japan
}

(Manuscript received 10 August 2019, in final form 11 May 2020)

\begin{abstract}
Precipitation characteristics and their environments are compared between two heavy rainfall events affecting the Northern Kyushu area in Japan: the July 2018 heavy rainfall event (2018 case) and the 2017 Northern Kyushu rainfall event (2017 case). Both events occurred in the later stage of the Baiu season, after the passage of a tropical cyclone, to the south of a subtropical jet, and on the front side of an upper tropospheric trough. However, contrasting precipitation properties and environments are observed between these cases. In the 2018 case, long-lasting, heavy precipitation was observed over a large area with moderately tall precipitation systems. The environment was stable and moist compared to the climatology. A deep trough over the Korean Peninsula prepared a favorable environment for organizing precipitation systems through moistening the mid-troposphere by quasi-geostrophic dynamically forced ascent. In contrast, in the 2017 case, short-term, intense precipitation was observed over a small area with exceptionally tall precipitation systems. The environment was unstable and moist, compared with the climatology, but was dryer than it was in the 2018 case. In the 2017 case, a shallow trough over the Korean Peninsula destabilized the atmosphere via associated high-altitude cold air.

The observed contrast of characteristics between the 2018 and 2017 cases was similar to that found between the composites of extreme rainfall events and extremely tall convection events, included in the previous statistical study by Hamada and Takayabu (2018, doi:10.1175/JCLI-D-17-0632.1). Although the previous study analyzed the uppermost $0.1 \%$ of extreme events, temperature anomalies and specific humidity anomalies from climatological values in the 2018 and 2017 cases are several times larger than those in the composites of the extreme events. This result indicates that the 2018 case was an extreme among the extreme rainfall events, and the 2017 case was an extreme one among the extremely tall convection events.
\end{abstract}

Keywords extreme rainfall event; upper tropospheric trough; Baiu; precipitation system

Citation Tsuji, H., C. Yokoyama, and Y. Takayabu, 2020: Contrasting features of the July 2018 heavy rainfall event and the 2017 northern Kyushu rainfall event in Japan. J. Meteor. Soc. Japan, 98, 859-876, doi:10.2151/jmsj.2020-045.

\section{Introduction}

From June 28 to July 8, 2018, heavy rainfall occurred in an extensive area of Japan, causing disastrous floods and landslides. The heavy rainfall during July 5-8 caused particularly disastrous damages in the

Corresponding author: Hiroki Tsuji, Atmosphere and Ocean Research Institute, The University of Tokyo, 5-1-5 Kashiwanoha, Kashiwa, Chiba 277-8568, Japan

E-mail: h-tsuji@aori.u-tokyo.ac.jp

J-stage Advance Published Date: 2 June 2020 western part of Japan. This rainfall event was characterized by an unusually large amount of precipitation within 48 to 72 hours (Shimpo et al. 2019; Tsuguti et al. 2018). The total precipitation between June 28 and July 8 exceeded $500 \mathrm{~mm}$ in an extensive area of western Japan and amassed a maximum of $1800 \mathrm{~mm}$. Some areas experienced precipitation two to four times higher than the monthly climatology for July during this event (Shimpo et al. 2019; Tsuguti et al. 2018). Using Global Precipitation Measurement satellite observation data, Yokoyama et al. (2020) showed 
that a precipitation system in this event was characterized by precipitation top heights that were mostly lower than $10 \mathrm{~km}$. Lower flash rates were also a characteristic feature of this rainfall event (Kawano et al. 2018). Some previous studies of this event reported extreme amounts of moisture. Takemura et al. (2019) showed that vertically integrated water vapor flux, and its convergence into western Japan area, was the highest in 60 years. Takemi and Unuma (2019) pointed out that precipitable water during this event was extremely higher than the climatological values for warm season quasi-stationary convective clusters in Japan (Unuma and Takemi 2016). Hereafter, this rainfall event is referred to as the "2018 case".

During July 5-6, 2017, a heavy rainfall event occurred in the Northern Kyushu area, resulting in flash floods and landslides in Fukuoka and Oita prefectures. Unlike the 2018 case, this rain event was characterized by intense precipitation over a short period. An Automated Meteorological Data Acquisition System (AMeDAS) Japan Meteorological Agency (JMA) rain gauge at Asakura city in Fukuoka prefecture recorded $129.5 \mathrm{~mm}$ rainfall in one hour and $261.0 \mathrm{~mm}$ in three hours (Kato et al. 2018a). Some AMeDAS stations measured nearly an entire month's amount of precipitation within 24 hours (Japan Meteorological Agency 2017). Kato et al. (2018b) reported that tall cumulonimbus clouds, with cloud tops higher than $15 \mathrm{~km}$, were observed with $\mathrm{X}$-band multiparameter radar. In this rain event, higher flash rates are reported by Kawano et al. (2018). Hereafter, this rainfall event is referred to as the "2017 case".

These two cases have several commonalities:

- a heavy rainfall was observed in an area that included the northern part of Kyushu island;

- the rainfall occurred in the later stage of Baiu, a cyclical cloudy and rainy season occurring in the early summer;

- the rainfall area was located to the south of the Baiu front;

- an upper tropospheric trough was observed over the Korean Peninsula; and

- a tropical cyclone passed around Kyushu island before the rainfall event.

Despite these similarities, there are several contrasting precipitation characteristics between the two cases. In this study, we investigated the source of these contrasts.

Many previous studies about heavy rainfalls in Japan have emphasized the importance of mesoscale structures and lower tropospheric characteristics, such as a low-level jet, moisture convergence in the bound- ary layer, and topographic effects (e.g., Akiyama 1975; Ninomiya and Yamazaki 1979; Ogura et al. 1985; Nagata and Ogura 1991; Kato et al. 2003; Tsuguti and Kato 2014). Sekizawa et al. (2019) pointed out the importance of moisture flux and latent heat flux at lower levels in the 2018 case. Takemi (2018) demonstrated that the representation of model terrains is an important factor in simulating the 2017 case precipitation systems.

The upper tropospheric phenomena and large-scale conditions for precipitation around Japan are also significant factors for rainfall events. Sampe and Xie (2010) demonstrated the importance of a subtropical jet to anchor the Meiyu-Baiu rain band. A subtropical jet supports an environment favorable for organizing precipitation systems through the moistening of the mid-troposphere (Yokoyama et al. 2017). Horinouchi (2014) and Horinouchi and Hayashi (2017) showed that, in mid-summer, precipitation is enhanced along with a subtropical jet. Ninomiya and Akiyama (1992) pointed out the importance of multi-scale characteristics on the Baiu fronts. Hirota et al. (2016) investigated a heavy rainfall event that occurred in Hiroshima, Japan in August 2014 and demonstrated the importance of free tropospheric moisture and an upper tropospheric disturbance to enhance the precipitation. The importance was confirmed statistically over the western North Pacific by Tsuji and Takayabu (2019).

Hamada et al. (2015) demonstrated, using spaceborne precipitation radar observations from the Tropical Rainfall Measuring Mission (TRMM) satellite, that extremely tall convections do not necessarily bring extreme rainfall events. Hamada and Takayabu (2018, hereafter, HT18) further compared characteristics of the extreme rainfall events and those of the extreme convection events around Japan in mid-summer, and demonstrated their differences. Their findings indicate that extreme rainfall events have wider rain areas, a higher stratiform area ratio, and a lower flash rate than extreme convection events. The environmental conditions for extreme rainfall events are relatively more stable and moister than the climatology, while those in extreme convection events are more unstable and drier than the climatology.

Based on these preceding studies, we investigate the contrasting features of the two heavy rainfall cases by comparing precipitation properties and environments. We also discuss the previous statistical study by HT18. We begin by describing the data used in this study and methodology (Section 2). We confirm the different precipitation properties, based on JMA radar data in Section 3, and then investigate environmental 
differences and the roles of an upper tropospheric trough in Section 4. In Section 5, our contrasting aspects between the 2018 and 2017 cases are compared to those in the statistical results found by HT18. The conclusions of this study and discussion are in Section 6.

\section{Data and methodology}

\section{$2.1 \quad$ Data}

The Japanese 55-year Reanalysis dataset (JRA-55) (Kobayashi et al. 2015; Harada et al. 2016) is used to analyze the environments. The JRA-55 provides global six-hourly atmospheric variables at a $1.25^{\circ} \times 1.25^{\circ}$ spatial resolution. We use the following variables: potential vorticity $(\mathrm{PV})$, precipitable water, specific humidity, temperature, vertical velocity, and horizontal wind variables. JMA radiosonde upper-air observation data at Fukuoka (Fig. 1) are also used to confirm vertical profiles obtained from JRA-55 (not shown).

We also use the grid point values of JMA weather radar data, which are made from 20 operational C-band radar observation data corrected with JMA rain gauge data (Japan Meteorological Agency observations department 2004). This dataset provides radarecho intensity converted into precipitation with a horizontal resolution of $1 \mathrm{~km}$ and echo-top height with horizontal resolution of $2.5 \mathrm{~km}$ every ten minutes. Data with echo-top height lower than $2 \mathrm{~km}$ are treated as no echo because they often have values when precipitation is not observed. These data are used to confirm precipitation characteristics. The synoptic distribution of precipitation is confirmed by analyzing the Global Satellite Mapping of Precipitation data (GSMaP_MVK version 7; Kubota et al. 2007; Aonashi et al. 2009).

\subsection{Methodology}

\section{a. Anomaly data}

Anomalies from climatological averages are used as temperature and specific humidity anomalies to analyze synoptic conditions. The climatological average is defined as an average between 1989 and 2010 at each JRA55 grid for each 6 hourly timestep of the calender day.

\section{b. Area average}

We calculate area-averaged precipitation to confirm the precipitation property of the two rainfall cases. The area average is calculated in a Northern Kyushu area, where heavy rainfall occurred in both the 2018 and 2017 cases (surrounded by a red rectangle in Fig. 1 ), and in a Setouchi area, where record breaking

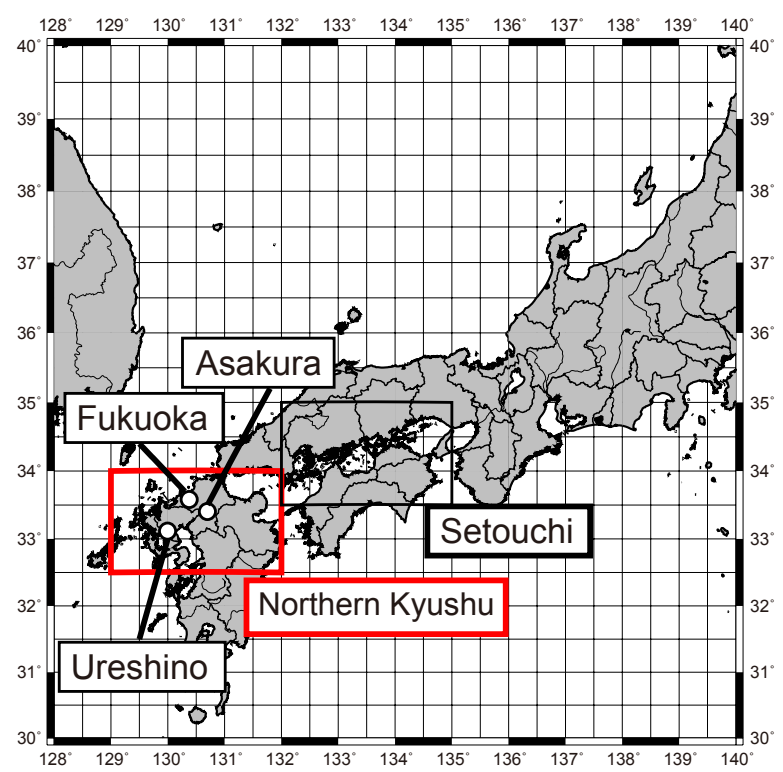

Fig. 1. A map of the Northern Kyushu area, the Setouchi area, and geographical locations referred to in the text.

rainfalls are observed in many AMeDAS stations for the 2018 case (surrounded by a black rectangle in Fig. 1). We also calculate accumulated precipitation and area-averaged frequency of echo-top heights for the same areas. The frequency of echo-top heights is normalized by total number of precipitating grids at each timestep.

\section{c. Evaluation of quasi-geostrophic forcing for vertical motion}

The dynamical forcing to the vertical motion associated with the upper tropospheric trough is evaluated by calculating the Q-vector (Hoskins et al. 1978). Following Holton (2004), the Q-vector form of the omega equation is defined as

$$
\sigma \nabla^{2} \omega+f_{0}^{2} \frac{\partial^{2} \omega}{\partial p^{2}}=-2 \nabla \cdot \mathbf{Q}+f_{0} \beta \frac{\partial v_{g}}{\partial p}-\frac{\kappa}{p} \nabla^{2} J,
$$

where

$$
\mathbf{Q}=\left(-\frac{R}{p} \frac{\partial \boldsymbol{V}_{g}}{\partial x} \cdot \nabla T,-\frac{R}{p} \frac{\partial \boldsymbol{V}_{g}}{\partial y} \cdot \nabla T\right),
$$

$\sigma$ is a standard atmosphere static stability parameter, $\omega$ is the vertical velocity, $f_{0}$ is the Coriolis parameter, $p$ is pressure, $T$ is temperature, $R$ is the gas constant, 
(a) 2018 case

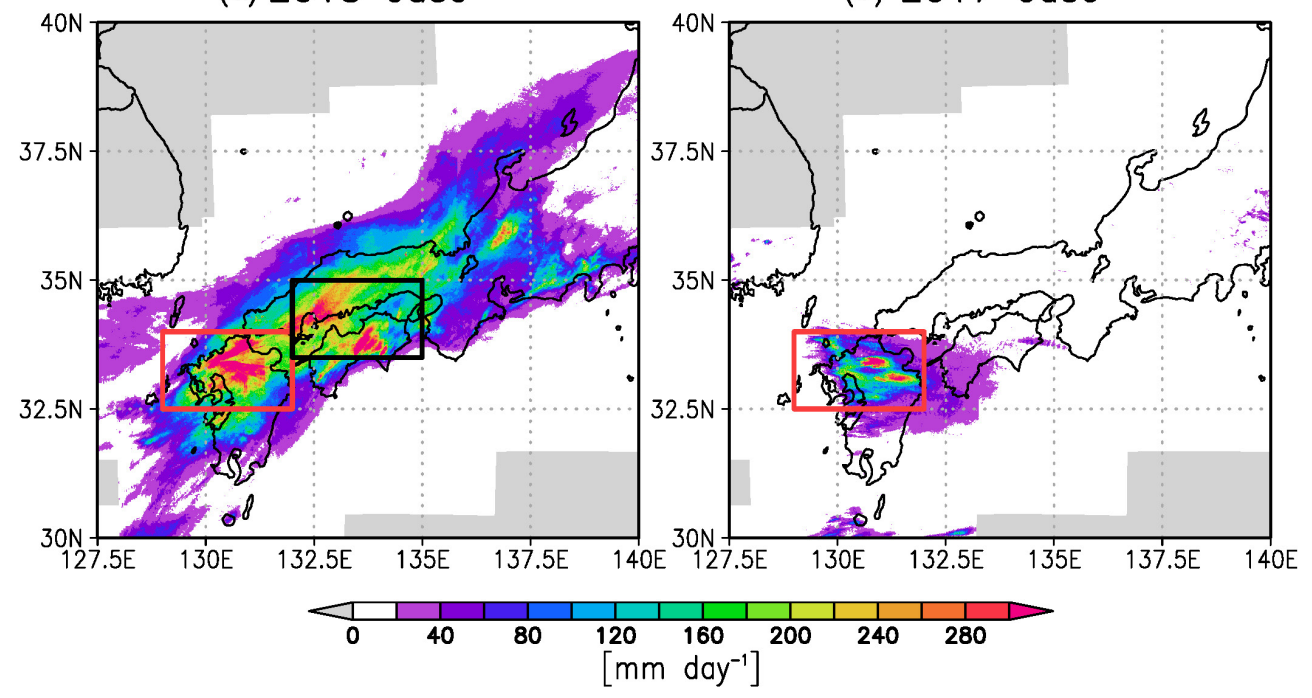

Fig. 2. Accumulated precipitation within (a) 24 hours from 18 UTC 5 July, 2018 to 18 UTC 6 July, 2018 and (b) 24 hours from 00 UTC 5 July, 2017 to 00 UTC 6 July, 2017. Red and black rectangles designate the Northern Kyushu area and Setouchi area, respectively.

$\boldsymbol{V}_{g}=\left(u_{g}, v_{g}\right)$ is a geostrophic wind vector obtained by geopotential height, $x$ and $y$ are eastward and northward distances, $\beta$ is the variation in the Coriolis parameter with latitude, $\kappa$ is the ratio of the gas constant to the specific heat at constant pressure, and $J$ is the diabatic heating rate. In this study, we focus on the quasi-geostrophic $(\mathrm{QG})$ forcing term $(-2 \boldsymbol{\nabla} \cdot \mathbf{Q})$. A positive QG forcing indicates ascending forcing.

Following Yokoyama et al. (2020), the QG forcing term is calculated with the following procedure. At first, we convert grid data of geopotential height and temperature from $1.25^{\circ}$ to $2.5^{\circ}$ resolution by averaging each set of nine $1.25^{\circ}$-resolution grid cells (one central grid cell and all eight surrounding grid cells) with approximate weights of $1,0.5$, and 0.25 for the central cell, adjacent four cells, and four corner cells, respectively. Then, we conduct a smoothing, with a 1-2-1 filter, in both longitudinal and latitudinal directions over a $2.5^{\circ} \times 2.5^{\circ}$ grid to remove variations on a scale smaller than geostrophic motions. Using the smoothed variables, we calculate the QG forcing term.

\section{Precipitation characteristics}

First, we compare the precipitation characteristics between the 2018 and 2017 cases based on the JMA operational radar observation data. Figure 2 shows the accumulated precipitation distributions within 24 hours from 18 UTC 5 July to 18 UTC 6 July for the 2018 case, and 24 hours from 0 UTC 5 July to 0 UTC 6 July for the 2017 case, around the time when large amounts of precipitation are observed in the Northern Kyushu area (cf. Fig. 3). In the 2018 case, precipitation greater than $100 \mathrm{~mm}^{-1 a y}{ }^{-1}$ was observed over a wide area, ranging from the Northern Kyushu area to approximately $138^{\circ} \mathrm{E}$. In contrast, precipitation was confined in the Northern Kyushu area in the 2017 case.

Figures $3 a-c$ show time-evolution of area-averaged precipitation. Precipitation related to the 2018 case is observed during 18 UTC 4 July to 0 UTC 7 July in the Northern Kyushu area (Fig. 3a). Roughly three peaks of area-averaged precipitation are found (around 9 UTC 5 July, 18 UTC 5 July, and 6 UTC 6 July, Fig. 3a). A large amount of the area-averaged precipitation is found during 15 UTC 5 July to 0 UTC 7 July, reaching a maximum at around 6 UTC 6 July (Fig. 3a). In the Setouchi area, precipitation related to the 2018 case is observed from 12 UTC 4 July to 12 UTC 7 July. A time-evolution of the area-averaged precipitation in the Setouchi area also show three peaks (around 0 UTC 5 July, 0 UTC 6 July, and 18 UTC 6 July, Fig. 3b). In the 2017 case, precipitation related to the rainfall event is observed from 0 UTC 5 July to 0 UTC 6 July with a maximum at 20 UTC 5 July (Fig. $3 \mathrm{c})$.

Comparing the two cases for the Northern Kyushu 
(a)

(b)

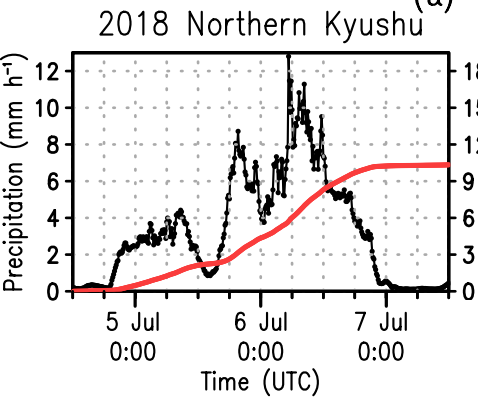

(d)

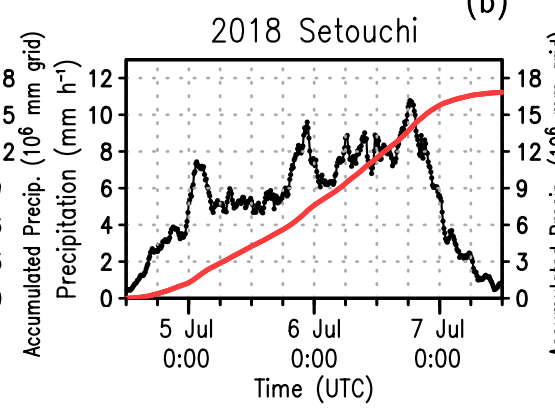

(e) (c)

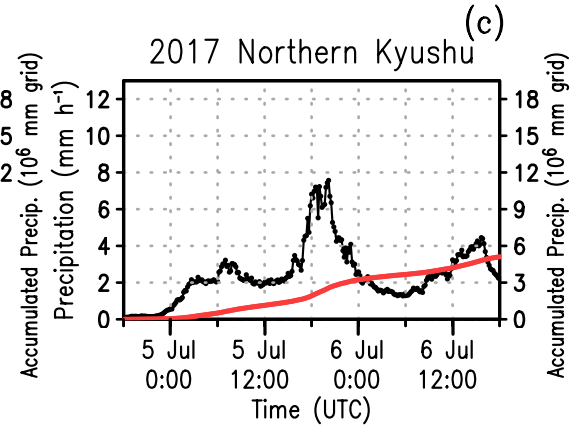

(f)
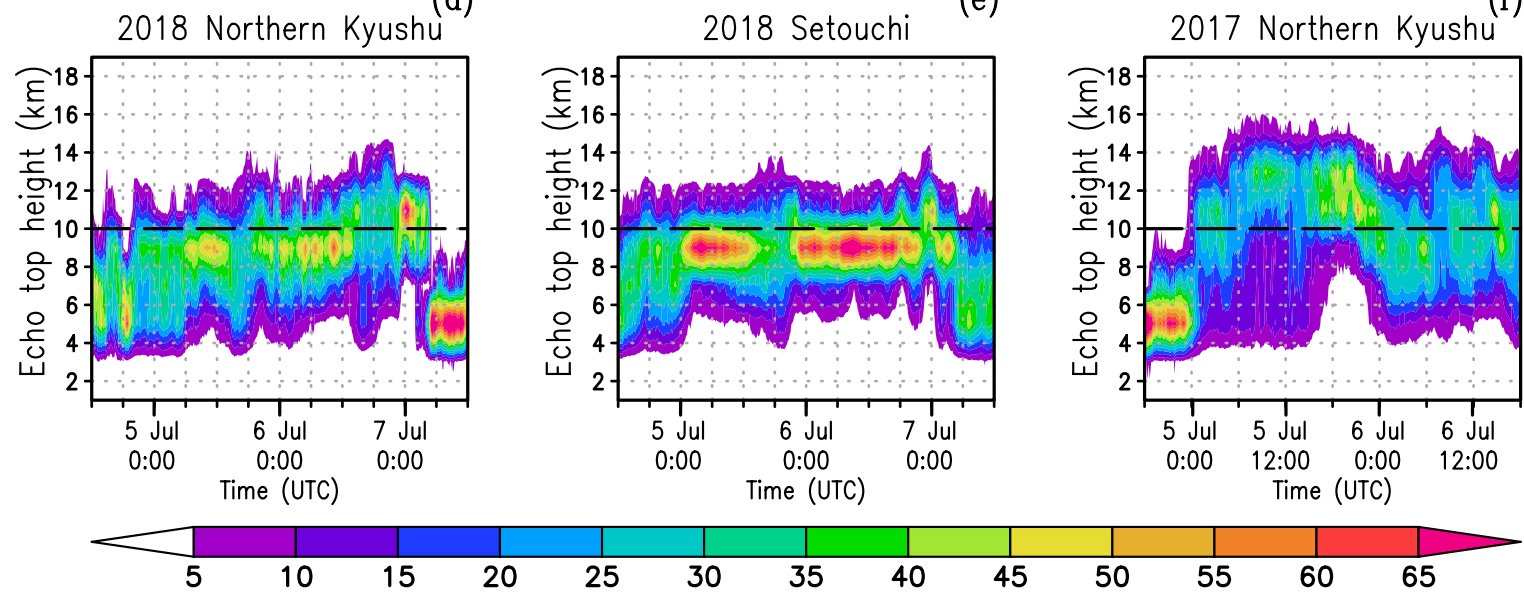

35
$[\%]$

Fig. 3. (a-c) Time-evolutions of area-averaged hourly precipitation ( $\mathrm{mm} \mathrm{h}^{-1}$, black line, left axis) for (a) the Northern Kyushu area in the 2018 case, (b) the Setouchi area in the 2018 case, and (c) the Northern Kyushu area in the 2017 case. The red line indicates accumulated precipitation (mm grid, right axis) for each area from (a, b) 12 UTC 4 July and (c) 18 UTC 4 July. (d-f) Time-evolution of frequency for echo-top heights, normalized by total number of precipitating grids at each timestep, for (d) the Northern Kyushu area in the 2018 case, (e) the Setouchi area in the 2018 case, and (f) the Northern Kyushu area in the 2017 case. The ordinate designates echo-top height (km). The black dashed lines indicate $10 \mathrm{~km}$.

area, the maximum area-averaged precipitation in the 2018 case (Fig. 3a) is about 1.5 times larger than the 2017 case (Fig. 3c). Additionally, the accumulated precipitation related to the rainfall events for the box area of the Northern Kyushu area in the 2018 case (10 $\times 10^{6} \mathrm{~mm}$ grid, Fig. 3a) is twice as large as it is in the 2017 case $\left(5 \times 10^{6} \mathrm{~mm}\right.$ grid, Fig. $\left.3 \mathrm{c}\right)$. On the other hand, the maximum precipitation per hour observed in AMeDAS stations in the Northern Kyushu area in the 2018 case was $84.5 \mathrm{~mm}$ (an hour till 7:38 UTC 6 July at Ureshino (Fig. 1), Japan Meteorological Agency 2018), while that in the 2017 case was $129.5 \mathrm{~mm}$ (an hour till 6:38 UTC 5 July at Asakura (Fig. 1), Japan Meteorological Agency 2017). This indicates that, in a short period, the precipitation intensity in the 2017 case was larger than the 2018 case.
Time-evolutions of echo-top height frequencies normalized at each timestep clarifies different precipitation characteristics for each of the two cases (Figs. $3 d-f)$. Precipitation with echo-top heights lower than $10 \mathrm{~km}$ is dominant when large precipitation rate is observed in the 2018 case (Fig. 3d). The precipitation in the Setouchi area also shows the same characteristics (Fig. 3e). These results are consistent with Yokoyama et al. (2020), who noted that organized precipitation systems with precipitation top heights at $7-9 \mathrm{~km}$ are dominant for the 2018 case. In contrast, precipitation with echo-top heights higher than $10 \mathrm{~km}$ is dominant in the 2017 case, except for the period just around 0 UTC 6 July, after the maximum area-averaged precipitation (Fig. 3f). This result is consistent with Kato et al. (2018b), who reported extremely tall clouds 
(a) 2018

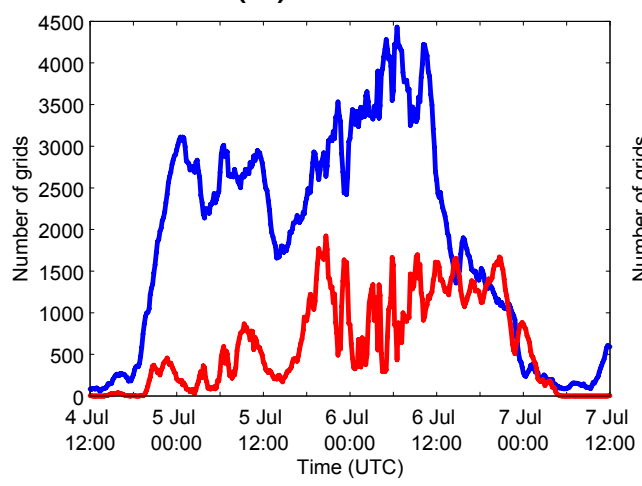

(b) 2017

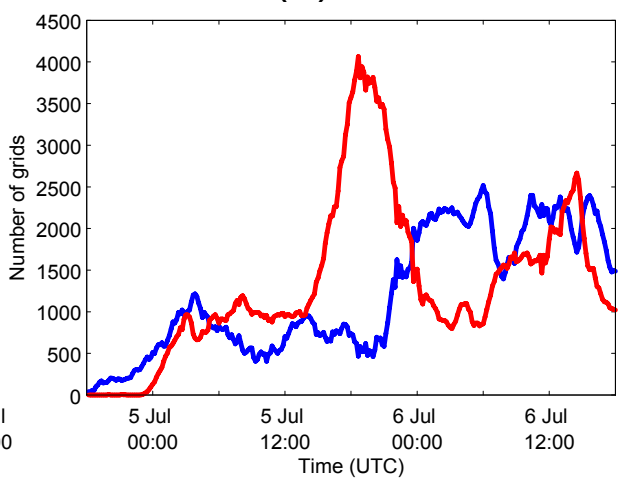

Fig. 4. Time-evolution of the number of grids observing an echo-top height lower than $10 \mathrm{~km}$ (blue lines) and higher than $10 \mathrm{~km}$ (red lines) in the Northern Kyushu area in (a) the 2018 case and (b) the 2017 case.

(echo-top height over $15 \mathrm{~km}$ ) in this case.

Figure 4 shows time-evolutions of grid numbers for echo-top heights lower than $10 \mathrm{~km}$ and echo-top heights higher than $10 \mathrm{~km}$, respectively, in the Northern Kyushu area for the two cases. In the 2018 case, precipitation with lower echo-top heights is at least twice as frequent as that with higher echo-top heights until 12 UTC on 6 July. In contrast, precipitation with higher echo-top heights is dominant until 0 UTC on July 6 in the 2017 case. In particular, precipitation with higher echo-top heights is five times more frequent than that with lower echo-top heights around 18 UTC on July 5.

These results indicate that long-lasting precipitation from lower-than-10 km echo-top heights occurred over a large area in the 2018 case. However, shortterm precipitation with higher-than-10 km echo-top heights occurred over a smaller area in the 2017 case. In the following analyses, the 2018 case analyses are limited to the Northern Kyushu area because the precipitation characteristics in the Setouchi area are similar to those analyzed in the Northern Kyushu area in terms of precipitation amount and echo-top heights.

\section{Contrasts in environment and roles of upper tropospheric troughs}

In this section, we investigate contrasts in the environment and the roles of upper tropospheric troughs between the two cases by analyzing synoptic conditions and the vertical structure of environmental variables.

\subsection{Synoptic conditions}

Synoptic conditions for the 2018 case are shown in Figs. 5 and 6. An upper tropospheric trough is analyzed over the Korean Peninsula and the Sea of Japan. The maximum value of $\mathrm{PV}$ associated with the trough reaches 10 PVU $\left(1 \mathrm{PVU}=10^{-6} \mathrm{~K} \mathrm{~m}^{2} \mathrm{~kg}^{-1} \mathrm{~s}^{-1}\right)$ over the Korean Peninsula on July 6 (Figs. 5c, d). Large gradients of geopotential at $300 \mathrm{hPa}$ are also analyzed around the trough (Fig. 6). The trough's southward extension is limited to the north of $30^{\circ} \mathrm{N}$ (Figs. 5, 6). A distinct upper westerly jet is analyzed, along with the trough, throughout the analysis period (Fig. 6). This trough maintains its location until 18 UTC 6 July, when it passes over the Northern Kyushu area. Precipitation occurrs over a wide area along the front side of the trough. A cold anomaly associated with the trough is analyzed over the Korean Peninsula, whereas a warm anomaly at $300 \mathrm{hPa}$ is found in front of the trough, which covers the Japanese islands (Fig. 6). The distribution of precipitable water is similar to that of the $300 \mathrm{hPa}$ warm anomaly except for formations north of $40^{\circ} \mathrm{N}$ (Fig. 5). Precipitable water greater than $60 \mathrm{~mm}$ is analyzed over a wide area, including the Northern Kyushu area. The maximum value of precipitable water reaches $70 \mathrm{~mm}$.

Synoptic conditions for the 2017 case are shown in Figs. 7 and 8. An upper tropospheric trough is observed over the Korean Peninsula as in the 2018 case. However, the maximum PV value associated with the trough is less than half of that in the 2018 case (Fig. 7) and the geopotential height contour gradient at 300 $\mathrm{hPa}$ around the trough is smaller (Fig. 8). A 1 PVU contour associated with the trough extends to around $25^{\circ} \mathrm{N}$, and the geopotential height contours at 300 $\mathrm{hPa}$ bends to southward at around $25^{\circ} \mathrm{N}$. An upper westerly jet is found along the trough, as in the 2018 
(a) 06Z05Jul2018

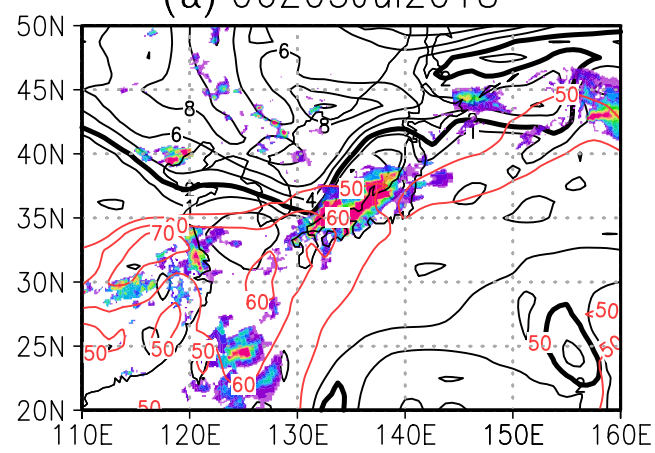

(c) 06Z06Jul2018

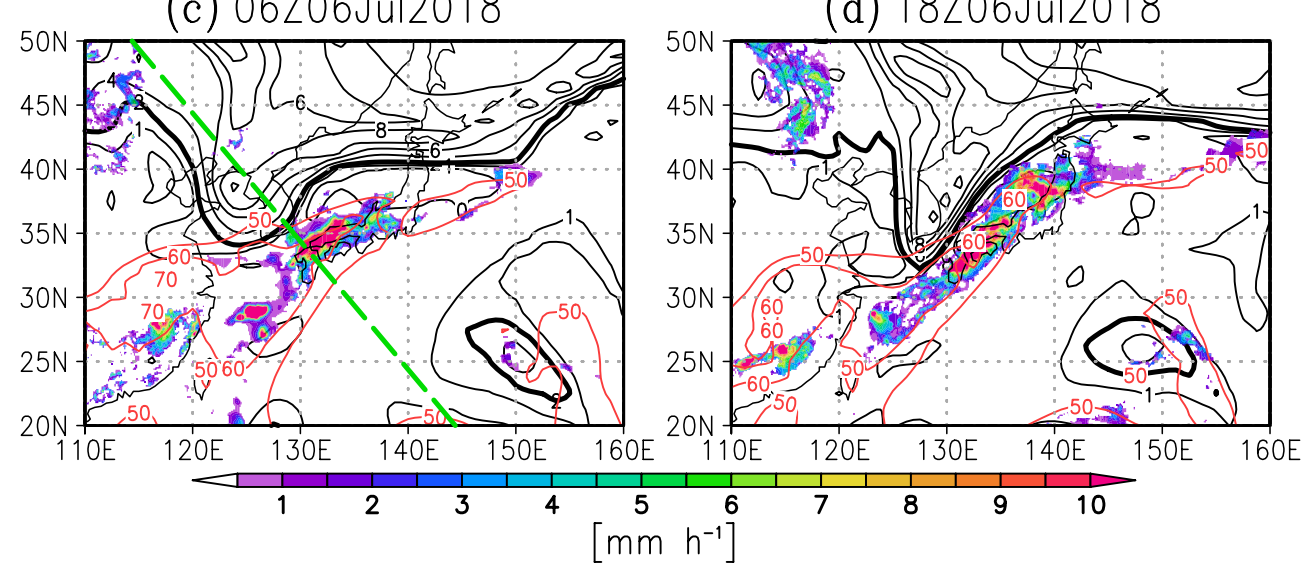

(b) 18Z05Jul2018

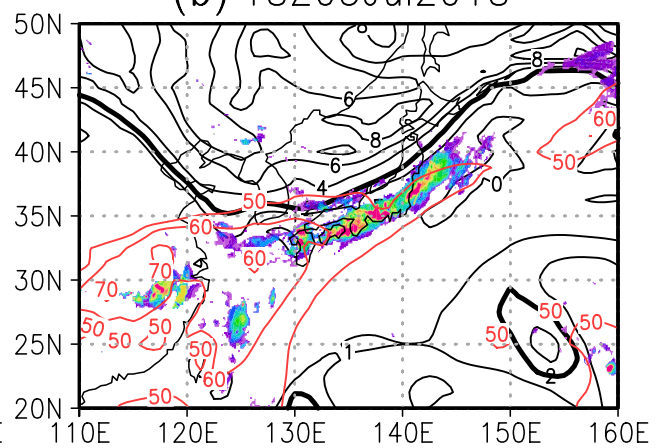

(d) 18Z06 Jul2018

Fig. 5. GSMaP rainfall rate (color, $\mathrm{mm} \mathrm{h}^{-1}$ ), $\mathrm{PV}$ on $350-\mathrm{K}$ isentropic surface (black contours, 2 PVU, 1 PVU contour is also drawn), and precipitable water (red contours, $10 \mathrm{~mm}$, only for $\geq 50 \mathrm{~mm}$ ) at (a) 6 UTC 5 July 2018, (b) 18 UTC 5 July 2018, (c) 6 UTC 6 July 2018, and (d) 18 UTC 6 July 2018. The bold black contours indicate the 2 PVU contour. The northwest-southeast diagonal dashed line in (c) marks the location of the cross-sectional analyses in Figs. 9-12.

case, but it is weaker and vague (Fig. 8). This trough passes over the Northern Kyushu area in only one day, in contrast to the 2018 case that takes two days. Precipitation occurred over a narrow area around the trough. A $300 \mathrm{hPa}$ cold anomaly associated with the trough is found over a wide area, including the Northern Kyushu area. Precipitable water over $50 \mathrm{~mm}$ is observed to the south of the upper westerly jet, over the East China Sea and southeastern China, like in the 2018 case (Fig. 7). However, the amount of precipitable water is smaller in the 2017 case. The area with precipitable water over $60 \mathrm{~mm}$ is limited compared to the 2018 case.

\subsection{Vertical structures}

In this subsection, vertical cross-sections in the 2018 case are compared with those in the 2017 case. We use snapshots at 6 UTC 6 July 2018 and 6 UTC
5 July 2017 as representatives of the 2018 and 2017 cases, respectively. These snapshots are selected as the nearest times when the maximum area-averaged precipitation is observed in the 2018 case (Fig. 3a), and when the maximum hourly precipitation is observed at the Asakura AMeDAS station in the 2017 case, respectively. For the 2017 case, we confirm that qualitatively identical results are obtained from another snapshots at 18 UTC 5 July, the nearest time to maximum area-averaged precipitation (Fig. $3 \mathrm{c}$ ). The vertical cross-sections are compared along the green dashed lines shown in Figs. 5c and 7b.

Based on vertical cross-sections of PV, the trough of the 2018 case looks deeper than the 2017 case. Figure 9 shows vertical cross-sections of $\mathrm{PV}$, vertical velocity, and pressure on an isentropic coordinate system. In the 2018 case, a 2 PVU contour, conventionally used as the definition of the dynamical tropopause (e.g., 
(a) 06Z05Jul2018

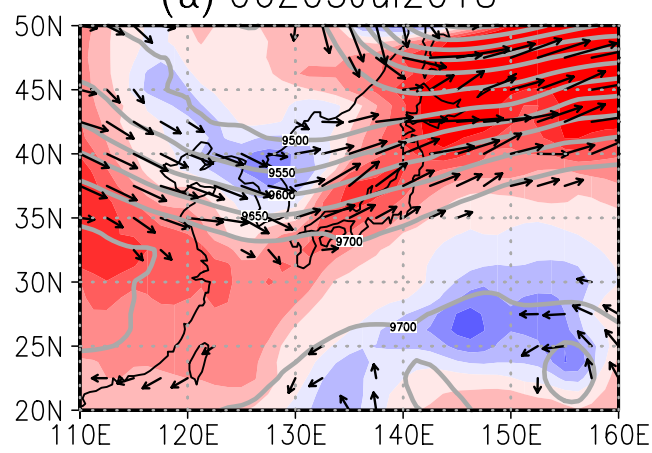

(c) 06Z06Jul2018

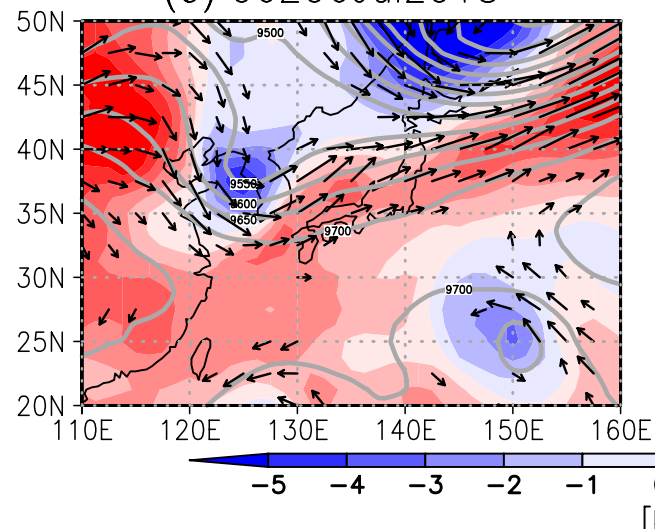

(b) 18Z05Jul2018

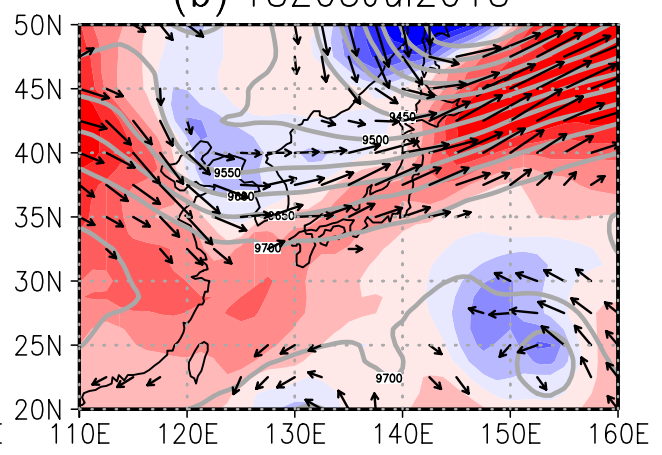

(d) 18Z06Jul2018

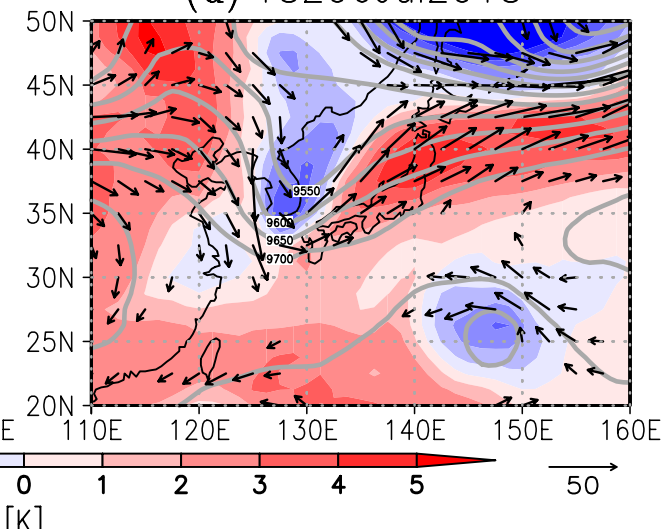

Fig. 6. Same as in Fig. 5, but showing temperature anomaly (color, K), geopotential height (contour, gpm), and wind vector $\left(\mathrm{m} \mathrm{s}^{-1}\right.$, only for $\left.\geq 20 \mathrm{~m} \mathrm{~s}^{-1}\right)$ at $300 \mathrm{hPa}$.

Hoskins et al. 1985; Holton et al. 1995; Martius et al. 2008), approaches $330 \mathrm{~K}$ at the trough near $125^{\circ} \mathrm{E}$, indicating a vertically deep trough (Fig. 9a). A 300 $\mathrm{hPa}$ isobaric line bend upward along a PV contour leading the trough. A similar upward bends are found for $500 \mathrm{hPa}$ and $700 \mathrm{hPa}$ isobaric lines, indicating that an effect of the upper tropospheric trough extended to the lower troposphere. In contrast, in the 2017 case, a 2 PVU contour does not cross the $300 \mathrm{hPa}$ line at the trough around $128^{\circ} \mathrm{E}$, indicating a vertically shallow trough (Fig. 9b). A $300 \mathrm{hPa}$ isobaric line bends slightly upward in front of the trough. However, $500 \mathrm{hPa}$ and $700 \mathrm{hPa}$ isobaric lines does not bend, as they does in the 2018 case.

Vertical distribution of the QG forcing term $(-2 \nabla \cdot \mathbf{Q})$ demonstrates a clear difference in dynamical effects of troughs between the two cases (Fig. 10). The dynamical forcing for ascent is analyzed throughout the troposphere around the ascending area in front of the trough $\left(130^{\circ} \mathrm{E}\right)$ in the 2018 case (Fig. 10a), indicating the trough's strong influence on the ascending motion. Yokoyama et al. (2020) evaluated the contribution of dynamically forcing and diabatic heating to the ascending motion in the 2018 case. They showed that the moisture flux convergence associated with the dynamically forced ascent accounted for about $30 \%$ of total moisture flux convergence associated with the QG ascent at mid-troposphere, indicating that the dynamical forcing played a non-negligible role to induce the ascending motion in the 2018 case. Takemura et al. (2019) also pointed out the importance of the dynamical forcing associated with the trough to the ascending motion. In the 2017 case, dynamical forcing for ascent associated with the trough is analyzed only above 400 $\mathrm{hPa}$ (Fig. 10b). Additionally, the magnitude of the dynamical forcing term in the upper troposphere is about one fourth of that in the 2018 case, indicating the trough's weak dynamical effect.

Vertical cross-sections of temperature anomaly also show differences between the two cases (Fig. 11). In the 2018 case, a warm anomaly is analyzed throughout the free troposphere around the ascending 
(a) 00Z05Jul2017

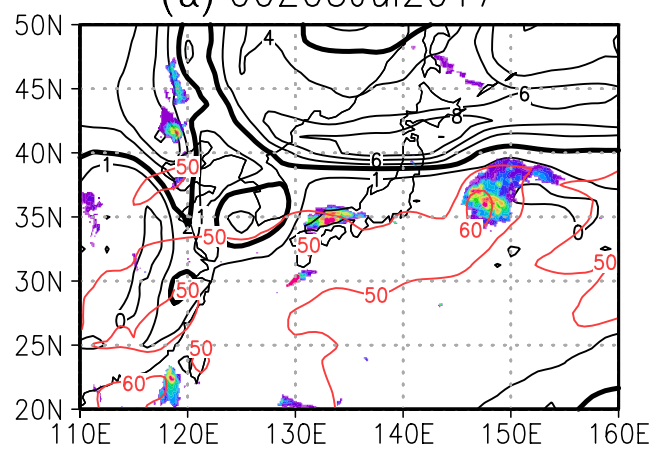

(c) 12Z05Jul2017

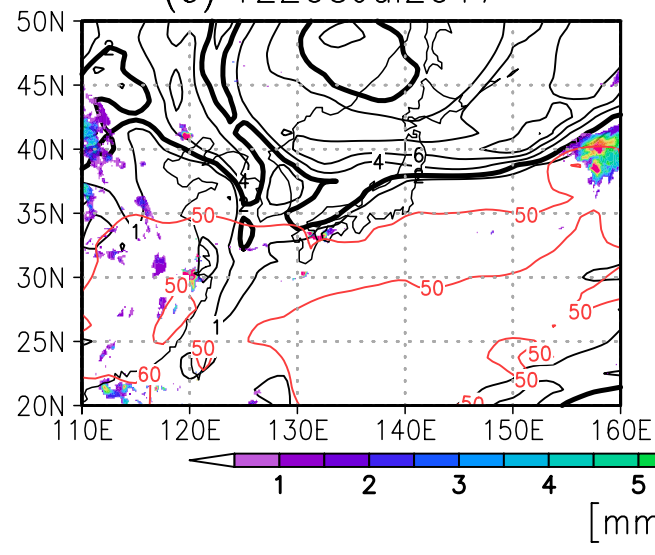

(b) 06Z05Jul2017

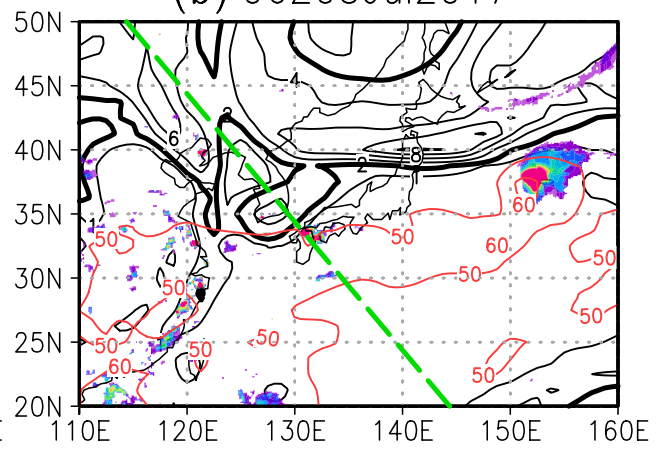

(d) 18Z05Jul2017

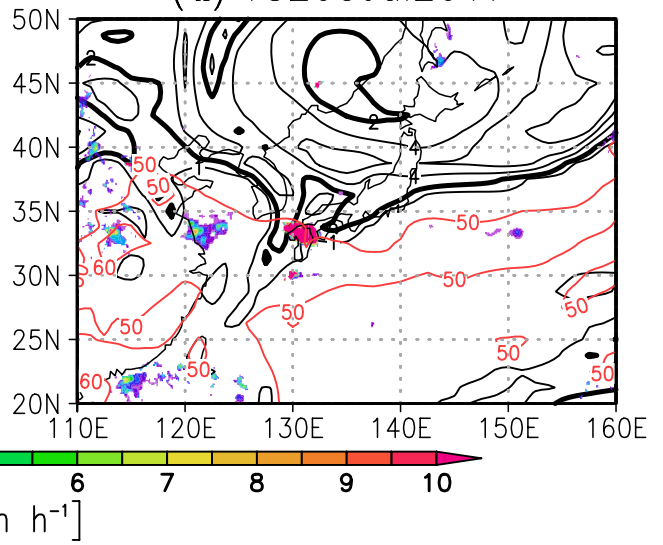

Fig. 7. Same as in Fig. 5, but for the 2017 case at (a) 0 UTC 5 July 2017, (b) 6 UTC 5 July 2017, (c) 12 UTC 5 July 2017, and (d) 18 UTC 5 July 2017. The northwest-southeast diagonal dashed line in (b) marks the cross-sectional analysis location in Figs. 9-12.

area, with a maximum at $250 \mathrm{hPa}$ (Fig. 11a). This warm anomaly is probably associated with the warm air advection leading the trough (cf. Fig. 6). A warm anomaly maximum, located in the upper troposphere, indicates a more stable stratification compared to the climatology. A cold anomaly is analyzed in a boundary layer around the ascending area extending from the northwest. This cold anomaly is associated with northeasterly lower tropospheric cold advection from the Okhotsk High (Shimpo et al. 2019; Moteki 2019), which enhances stable stratification. In contrast, a cold anomaly is analyzed throughout the free troposphere around the ascending area, with a maximum at 250 $\mathrm{hPa}$ in the 2017 case (Fig. 11b), indicating unstable stratification compared to the climatology. This cold anomaly is associated with a cold air mass associated with the trough (cf. Fig. 8). Because the trough extended southward, the cold anomaly associated with the trough can be found in west - east and southwest -northeast cross-sections (not shown). A warm anomaly is analyzed in the boundary layer, which enhanced the unstable stratification.

Specific humidity anomalies are distributed similarly in the two cases around the ascending area (Fig. 12). In the 2018 case, a positive anomaly is found throughout the troposphere around the ascending area, with a maximum value over $5 \mathrm{~g} \mathrm{~kg}^{-1}$ at $700 \mathrm{hPa}$, indicating a very moist environment. Yokoyama et al. (2020) showed that the upper tropospheric trough played an important role in producing the moist environment for the organized convective system for the 2018 case. In the 2017 case, the positive anomaly shows two peaks, at $850 \mathrm{hPa}$ and $700 \mathrm{hPa}$, around the ascending area. These peak values were only half the maximum value in the 2018 case, indicating that, although this environment was very moist, it was much drier than the 2018 case.

The different environments and roles of upper tropospheric troughs for the 2018 and 2017 cases are summarized as follows: In the 2018 case, an upper 
(a) 00Z05Jul2017

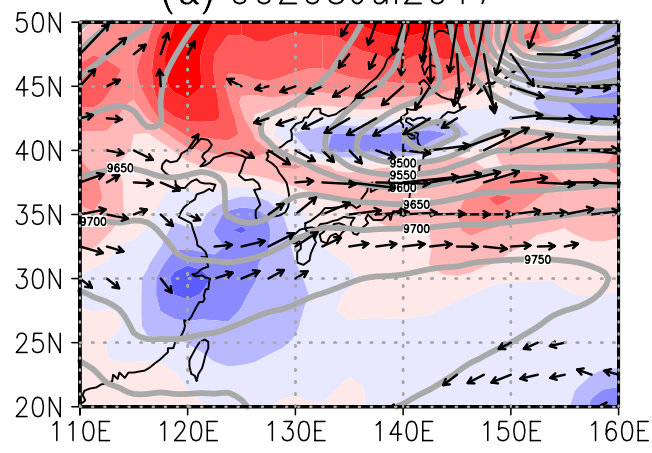

(c) 12Z05Jul2017

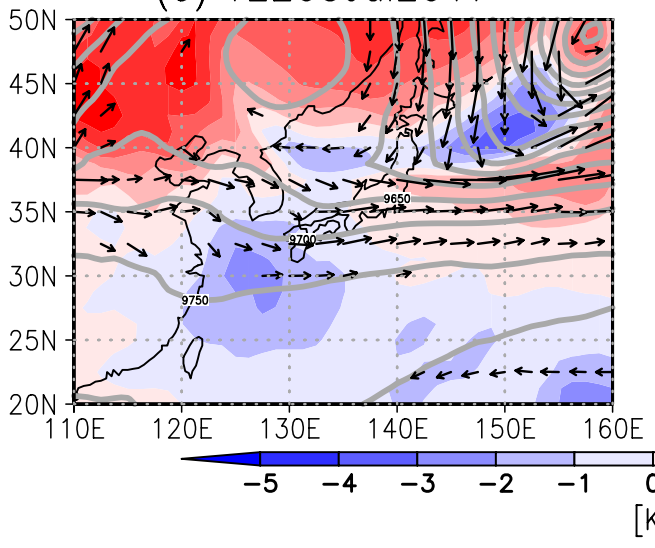

(b) 06Z05Jul2017

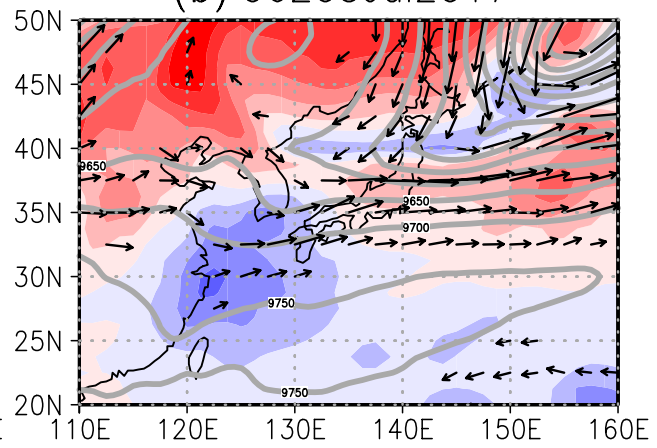

(d) 18Z05Jul2017

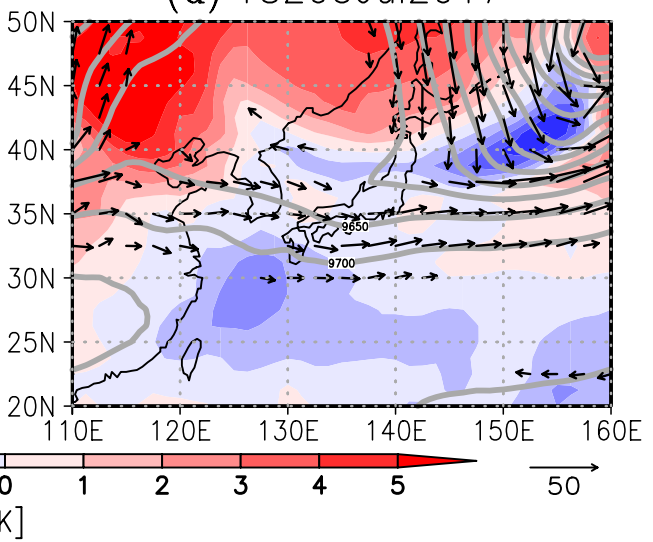

Fig. 8. Same as in Fig. 6, but for the 2017 case at (a) 0 UTC 5 July 2017, (b) 6 UTC 5 July 2017, (c) 12 UTC 5 July 2017, and (d) 18 UTC 5 July 2017.

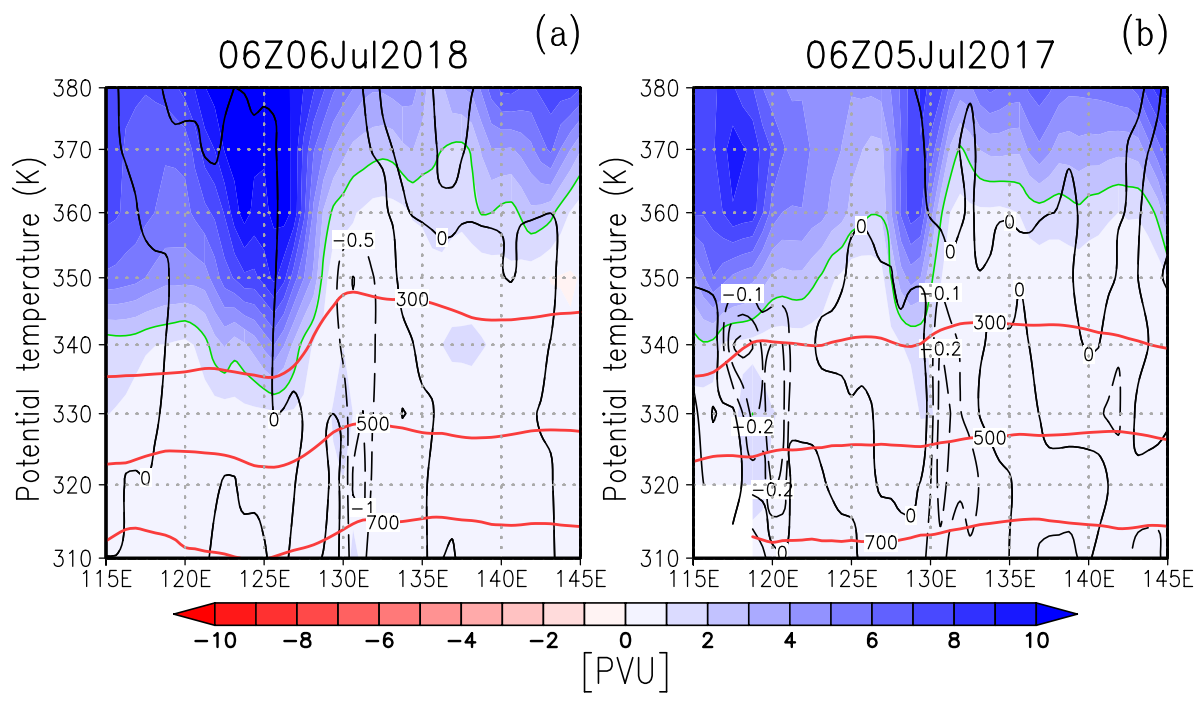

Fig. 9. Vertical cross-sections of PV (color, PVU) and vertical velocity (black contour, Pa s ${ }^{-1}$ ) for (a) the 2018 case and (b) the 2017 case, taken along the diagonal lines from (a) Fig. 5c and (b) Fig. 7b. The vertical velocity contour intervals are $0.5 \mathrm{~Pa} \mathrm{~s}^{-1}$ in (a) and $0.1 \mathrm{~Pa} \mathrm{~s}^{-1}$ in (b). The green contours indicate 2 PVU lines. Red contours indicate 300,500 , and $700 \mathrm{hPa}$ isobars. The abscissa shows longitude, and the ordinate shows potential temperature (K). 


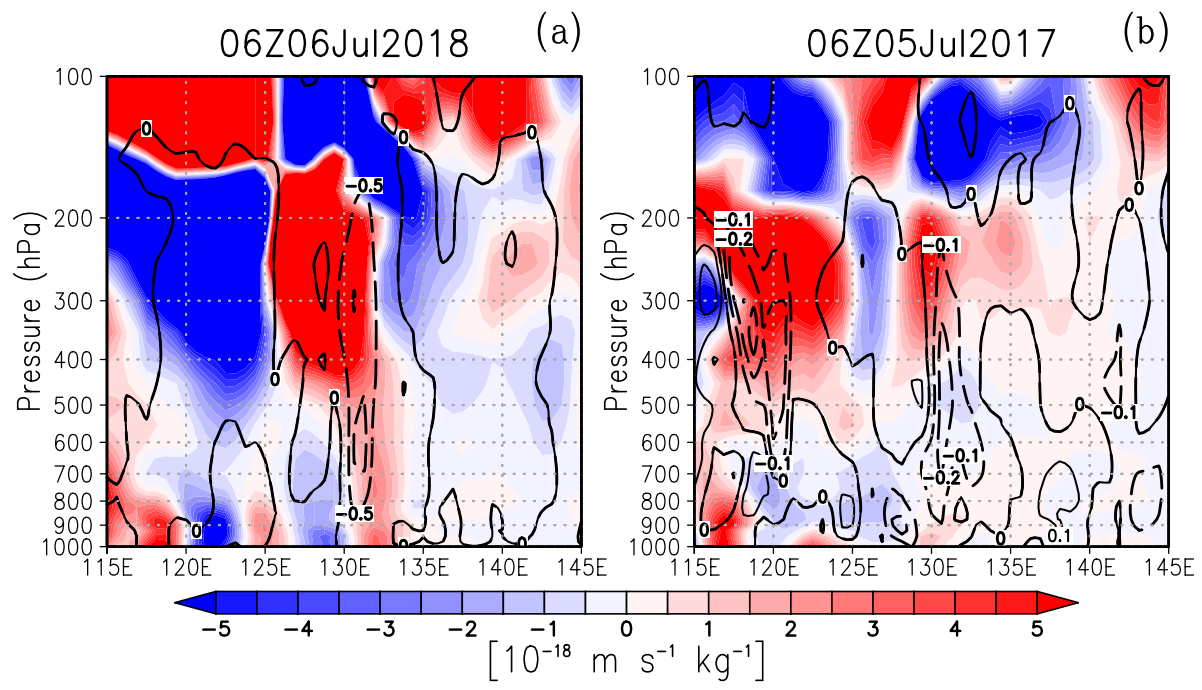

Fig. 10. Vertical cross-sections of QG forcing term $\left(-2 \nabla \cdot \mathbf{Q}\right.$, color, $\left.10^{-18} \mathrm{~m} \mathrm{~s}^{-1} \mathrm{~kg}^{-1}\right)$ and vertical velocity (contours) for (a) the 2018 case and (b) the 2017 case, taken along the diagonal lines from (a) Fig. 5c and (b) Fig. 7b. The vertical velocity contour intervals are $0.5 \mathrm{~Pa} \mathrm{~s}^{-1}$ in (a) and $0.1 \mathrm{~Pa} \mathrm{~s}^{-1}$ in (b). The abscissa shows longitude, and the ordinate shows pressure $(\mathrm{hPa})$.

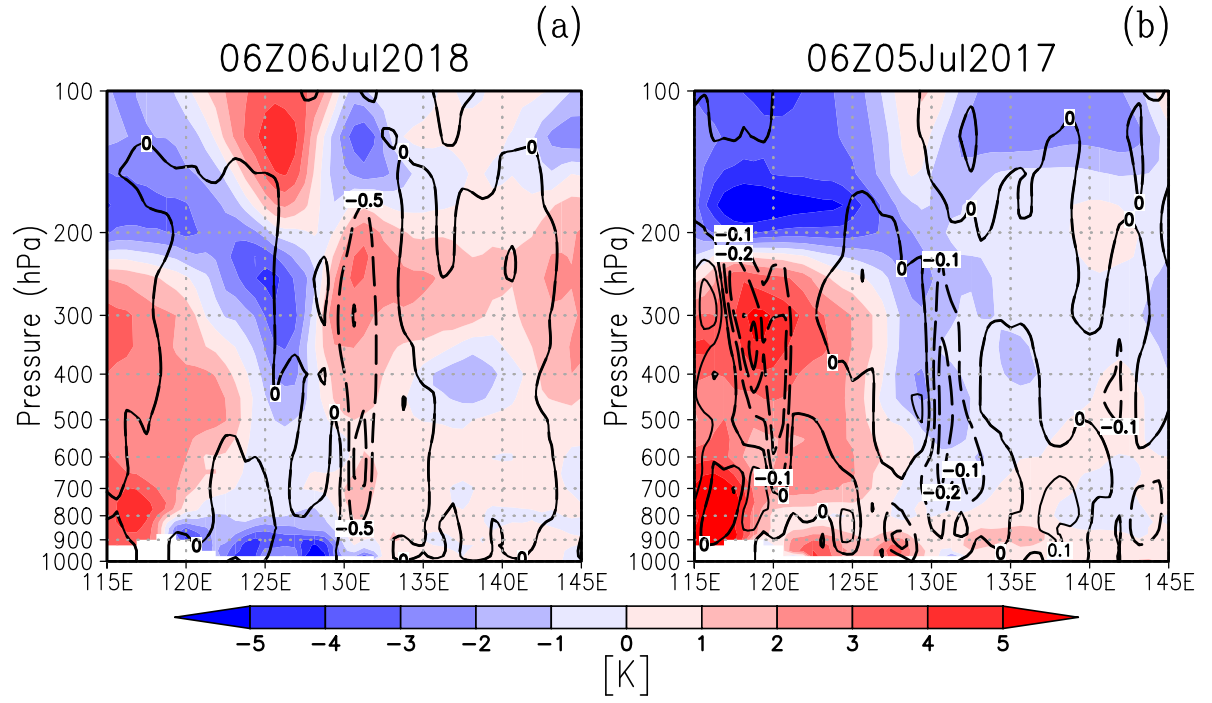

Fig. 11. As in Fig. 10, but showing temperature anomaly (color, K) and vertical velocity (contours) for (a) the 2018 case and (b) the 2017 case.

tropospheric trough, with a vertically deep structure, induced a dynamical ascent and provided a relatively stable environment compared to the climatology. In contrast, an upper tropospheric trough in the 2017 case had a vertically shallow structure, based on vertical extent of 2 PVU contour, which provided weak dynamical ascent. Instead, the trough helped destabi- lize the atmosphere and provided a relatively unstable environment compared to the climatology. Moist anomalies around the ascending area were found in both cases, but the 2017 atmosphere was drier than the 2018 atmosphere.

Note that, about the depth of troughs, if another index, such as the vertical extent of cold temperature 


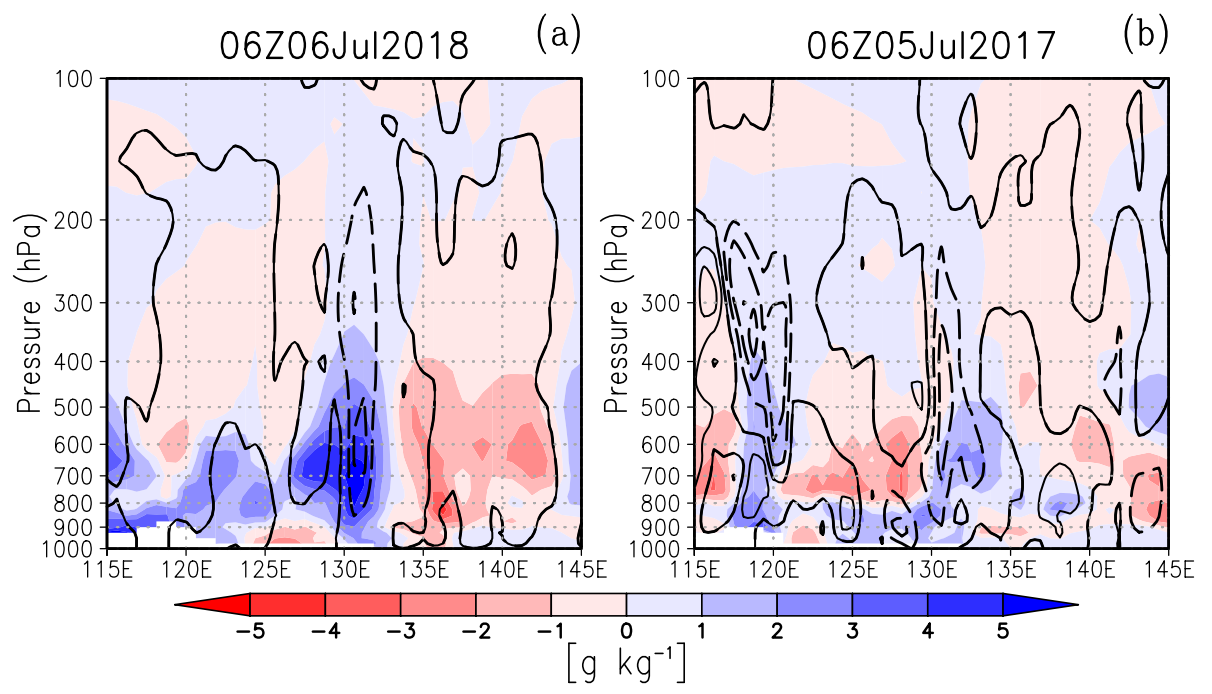

Fig. 12. As in Fig. 10, but showing specific humidity anomaly (color, $\mathrm{g} \mathrm{kg}^{-1}$ ) and vertical velocity (contours) for (a) the 2018 case and (b) the 2017 case.

anomaly, is used, the 2017 case's trough reaches around $600 \mathrm{hPa}$ (Fig. 11). However, in this report, we discuss the vertical depth with vertical extent of 2 PVU contours to analyze the structure of troughs in terms of dynamic perspective.

\section{Similarity of contrasts between the two cases to the statistics with the space-borne precipitation radar observation}

The contrast between the 2018 and 2017 cases, shown in the previous sections, is similar to that between statistics of the extreme rainfall events and the extreme convection events studied by HT18. "Extreme rainfall events" were defined as events where the maximum near-surface rainfall rates, observed by a precipitation radar on board the Tropical Rainfall Measuring Mission satellite (TRMM/PR), is within the uppermost $0.1 \%$. "Extreme convection events" were defined as events where the maximum $40-\mathrm{dBZ}$ height, observed by the TRMM/PR, is within the uppermost $0.1 \%$. HT18 demonstrated that extreme rainfall events had wider rain areas, higher stratiform area ratios, and lower flash rates than the extreme convection events. They also demonstrated that the environmental profiles for the composite of the extreme rainfall events were relatively more stable and moister compared with the climatology, whereas those in the extreme convection events were relatively less stable and dryer compared with the climatology.

In this section, we compare vertical profiles of environmental variables in the two cases with those described by HT18 (in Section 5.1). The vertical profiles are calculated from averages of four JRA55 grids around Fukuoka for 6 UTC 6 July 2018 and 6 UTC 5 July 2017, respectively. Qualitatively identical results are obtained for other timesteps used in Figs. 5-8 (not shown) and radiosonde upper-air observation at Fukuoka (not shown). We also compare horizontal distribution and flux of moisture in both cases with those shown in HT18 (Section 5.2).

\subsection{Comparison of vertical profiles}

The vertical profile of the temperature anomaly in the 2018 case (Fig. 13a, blue line) is similar to that of the composite of extreme rainfall events (Fig. 6e from HT18). In the 2018 case, a warm temperature anomaly is analyzed between $900 \mathrm{hPa}$ and $175 \mathrm{hPa}$, with a maximum at $225 \mathrm{hPa}$. The temperature anomaly monotonically decreases downward below $900 \mathrm{hPa}$. The warm and cold temperature anomaly maxima, from the composite of the extreme rainfall events, are at $200-300 \mathrm{hPa}$ and the lowest level, respectively (Fig. 6e from HT18). The maximum value of the warm temperature anomaly in the 2018 case is about six times larger than that in the composite of the extreme rainfall events, indicating that the atmosphere in the 2018 case is more stable than that it was the extreme rainfall composite compiled by HT18.

A similar vertical profile of the temperature anomaly in the 2017 case (Fig. 13a, red line) is depicted by the composite of the extreme convection events (Fig. 6e from HT18). In the 2017 case, a cold temperature 
(a)

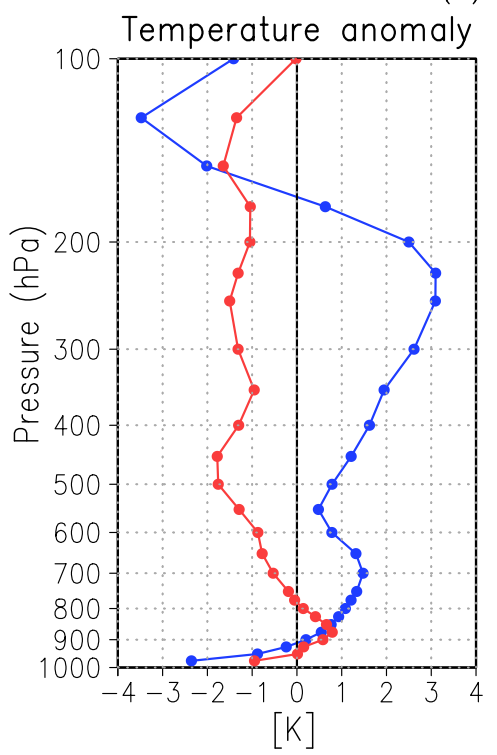

(b)

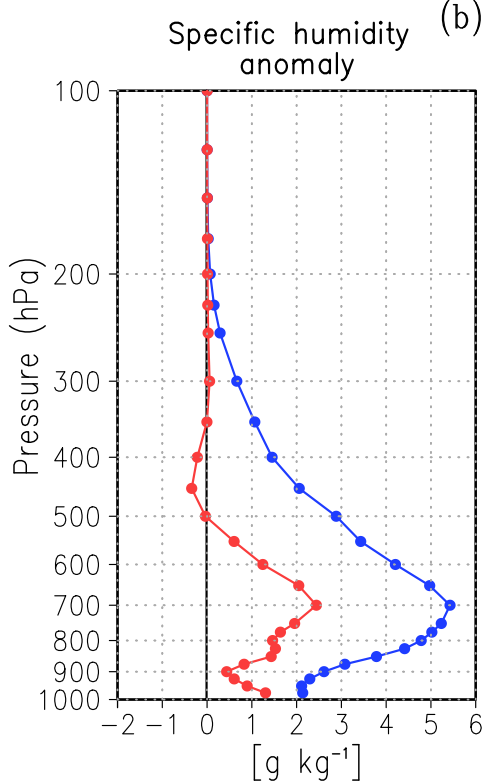

Fig. 13. Vertical profiles of (a) temperature anomaly (K) and (b) specific humidity anomaly ( $\left.\mathrm{g} \mathrm{kg}^{-1}\right)$ for the 2018 case (blue lines) and 2017 case (red lines). These profiles are averaged over four grids around Fukuoka on 6 UTC 6 July 2018 for the 2018 case and 6 UTC 5 July 2017 for the 2017 case.

anomaly is found above $800 \mathrm{hPa}$ with a maximum at $450 \mathrm{hPa}$. The maximum of the warm temperature anomaly is located at $875 \mathrm{hPa}$. A cold temperature anomaly in the extreme convection events composite is also confirmed at $200-700 \mathrm{hPa}$ with a maximum at 300-400 hPa (Fig. 6e from HT18). The maximum warm temperature anomaly is located at the lowest level. The maximum value of the cold temperature anomaly in the 2017 case is four times larger than that in the composite of the extreme convection events, indicating a more unstable atmospheric condition in the 2017 case compared with the extreme convection composite described by HT18.

On the other hand, the vertical profile of the specific humidity anomaly in the 2018 case (Fig. 13b, blue line) is similar to the vertical profile of the composite of the extreme rainfall events (Fig. 6h from HT18). A positive specific humidity anomaly is analyzed below $200 \mathrm{hPa}$, with a maximum at $700 \mathrm{hPa}$ in the 2018 case (Fig. 13b). In the composite of extreme rainfall events, a positive specific humidity anomaly is located below $300 \mathrm{hPa}$ with a maximum at $700-800 \mathrm{hPa}$ (Fig. $6 \mathrm{~h}$ of HT18). The maximum value of the specific humidity anomaly in the 2018 case is approximately ten times larger than that in the composite of extreme rainfall events, indicating that the atmosphere in the 2018 case was more humid than in the extreme rainfall composite.
The vertical profile of the specific humidity anomaly in the 2017 case (Fig. 13b, red line) is, however, different than it was in the composite of the extreme convection events studied in HT18 (Fig. 6h of HT18). A positive specific humidity anomaly is analyzed below $500 \mathrm{hPa}$, with a maximum at $700 \mathrm{hPa}$ in the 2017 case, whereas a negative humidity anomaly is confirmed below $300 \mathrm{hPa}$ in the composite of the extreme convection events.

These results indicate similarities in environmental profiles between the 2018 case and the composite of the extreme rainfall events, and between the 2017 case and the composite of the extreme convection events, respectively. The atmosphere in the 2017 case was moister than the climatology but was much drier than it was in the 2018 case. Thus, we can conclude that the contrast between the 2018 and 2017 cases is similar to that of the composites between the extreme rainfall and extreme convection events.

\subsection{Comparison of horizontal distributions of moisture and its flux}

Figure 14 shows composites for the vertically integrated moisture anomaly and its horizontal fluxes, in the free troposphere and in the boundary layer, for 2018 and 2017 cases. The vertical integration for the moisture anomaly $\langle(q)\rangle$ and its horizontal flux $\langle(q v)\rangle$ 


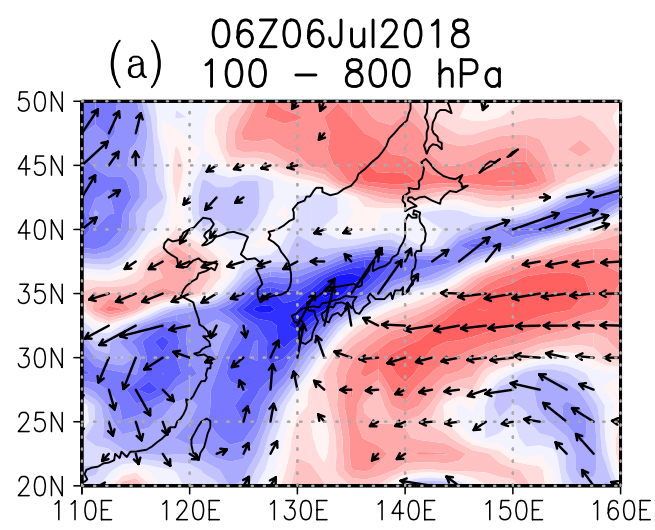

(c) 06ZO6Jul2018 $50 \mathrm{~N}$

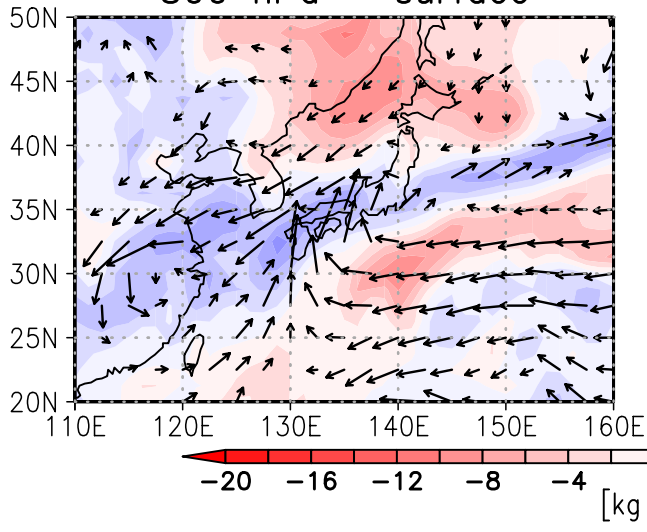

06Z05Jul2017

(b) $100-800 \mathrm{hPa}$

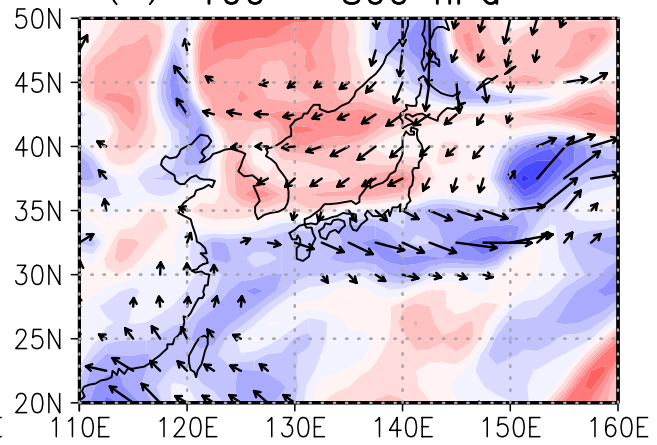

(d) 06Z05Jul2017 $800 \mathrm{hPa}$ - surface

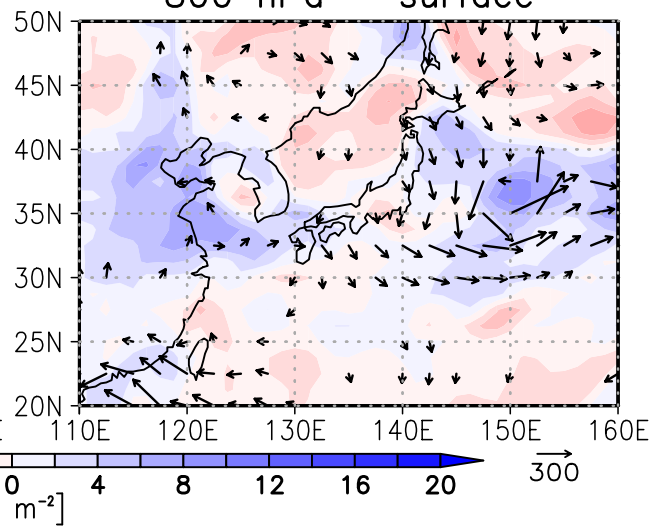

Fig. 14. Vertically integrated moisture anomaly (color, $\mathrm{kg} \mathrm{m}^{-2}$ ) and its horizontal flux (vector, $\mathrm{kg} \mathrm{m}^{-1} \mathrm{~s}^{-1}$, only for $\geq 75 \mathrm{~kg} \mathrm{~m}^{-1} \mathrm{~s}^{-1}$ ) for (a, c) the 2018 case and (b, d) the 2017 case. (a) and (b) show the results for the free troposphere (between 100 and $800 \mathrm{hPa}$ ), and (c) and (d) show the results for the boundary layer (between $800 \mathrm{hPa}$ and the surface).

are calculated following the methods of HT18:

$$
\langle()\rangle=\mathrm{g}^{-1} \int_{p_{2}}^{p_{1}}() \mathrm{dp},
$$

where $\mathrm{g}$ is gravity, and $p_{1}$ and $p_{2}$ are set to $100 \mathrm{hPa}$ and $800 \mathrm{hPa}$ for the free troposphere and 800 and the surface pressure for the boundary layer, respectively.

The horizontal distribution of moisture for the 2018 case (Figs. 14a, c) is similar to that in the composite of the extreme rainfall events (Figs. 7a, c from HT18). In the 2018 case, a large moisture anomaly is analyzed over the southern part of the Japanese islands, predominantly in the free troposphere (Fig. 14a). This elongated high anomaly area stretched from eastern China and the East China Sea to the western North Pacific to the east of Japan, like an atmospheric river confirmed in the western North Pacific regions (Mundhenk et al. 2016; Kamae et al. 2017). In fact, Yatagai et al. (2019) showed that an atmospheric river was detected during the 2018 case. Southerly and south-westerly fluxes are dominant around the Northern Kyushu area, both in the free troposphere and in the boundary layer.

For the 2017 case, northeasterly fluxes are found around the Northern Kyushu area both in the free troposphere and in the boundary layer (Figs. 14b, d), which is consistent with the extreme convection events composite (Figs. 7b, d from HT18). An anomalously large moisture belt is found in the free troposphere along the Japanese Archipelago, which corresponds to the track of a tropical cyclone that passed over Japan before the rainfall event. Except for this large, anomalous moist area, the moisture distribution is similar to that of the composite of the extreme convection events described by HT18.

The similarities shown in this section indicate that the 2018 case and 2017 case can, reasonably, 
(a) The 2018 case

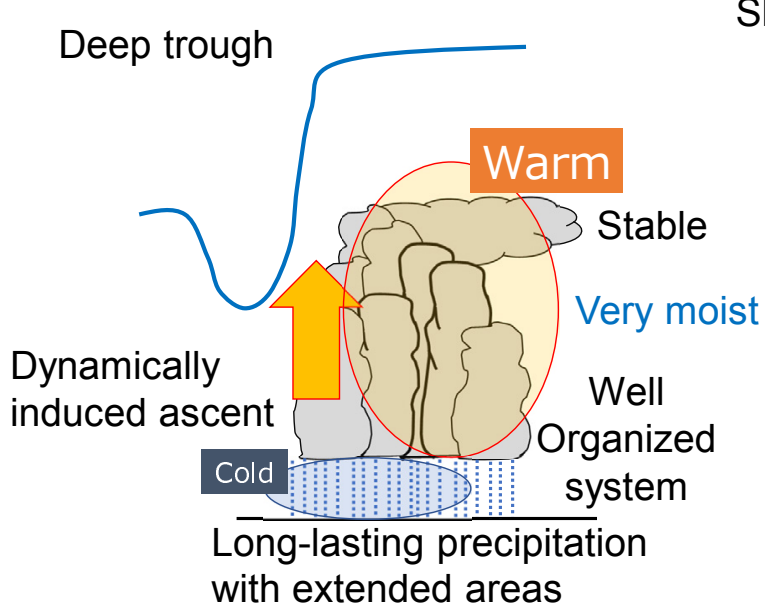

(b) The 2017 case

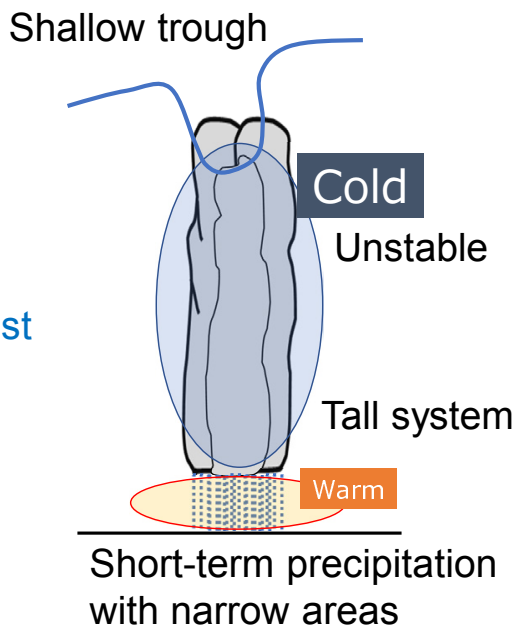

Fig. 15. Schematics of rainfall events for (a) the 2018 case and (b) for the 2017 case.

be considered to correspond to the extreme rainfall events and extreme convection events, respectively. The flash rate in the 2018 case was reported as smaller compared to that of the 2017 case (Kawano et al. 2018), which also supports this correspondence. Moreover, the amplitudes of the anomaly in the 2018 and 2017 cases are several times larger than those in the composites of extreme events, even though HT18's composites only included the uppermost $0.1 \%$ of extreme events. Thus, these results indicate that the 2018 case was an extreme among the extreme rainfall events, and the 2017 case was an extreme event of the extreme convection events. In fact, the total precipitation observed by AMeDAS stations for three-day periods during the 2018 case was the highest since 1982 (Shimpo et al. 2019). For the 2017 case, the Asakura AMeDAS station recorded the highest hourly and three-hourly precipitation for the station (Japan Meteorological Agency 2017). In particular, the highest three-hourly precipitation was about twice as large as the second highest three-hourly precipitation at Asakura.

\section{Conclusion and discussion}

Precipitation characteristics and environment are compared between the July 2018 heavy rainfall event (2018 case) and the 2017 Northern Kyushu rainfall event (2017 case). Our results indicate that the different precipitation characteristics between the two cases result from the different balance between roles of the troughs and the environmental stability.
Figure 15 illustrates environmental characteristics and precipitation systems for the two cases. In the 2018 case (Fig. 15a), an upper tropospheric trough was observed over the Korean Peninsula. This trough had a vertically deep structure. Dynamical forcing associated with the trough reached the lower troposphere around the Northern Kyushu area (Fig. 10a). Warm advection from the south and dynamical effect of the trough provided a relatively more stable stratification and a moister environment than the climatology around the Northern Kyushu area (Fig. 11a). The Okhotsk High helped stabilize the atmosphere with the northeasterly lower tropospheric cold advection. On the other hand, a cold anomaly area associated with the trough was limited in a narrow area around the Korean Peninsula because of the trough's small southward extension (Figs. 5, 6). These factors provided environments favorable for organized precipitation systems, resulting in a long-lasting rainfall from moderately tall precipitation systems over an extensive area.

In the 2017 case (Fig. 15b), an upper tropospheric trough was also observed over the Korean Peninsula. This trough had a vertically shallower structure than the 2018 case based on the vertical extent of 2 PVU contours. The QG forcing associated with this trough was weaker compared to the 2018 case (Fig. 10b). On the other hand, the cold anomaly associated with the trough was found over a wide area (Fig. 8), which provided a relatively less stable environment compared with the climatology (Fig. 11b) over the Northern 
Kyushu. Although the atmosphere was relatively moister than the climatology because a tropical cyclone had passed before the 2017 case, the atmosphere was relatively drier than the 2018 case (Fig. 13). These factors provided a favorable environment for tall convections, rather than large-scale organized systems, resulting in a short-duration heavy rainfall events over smaller areas from extremely tall precipitation systems.

The contrast of environments between the two cases corresponds well to that of the statistical results described by HT18. Moreover, the amplitudes of anomalies in the 2018 and 2017 cases are several times larger than those found in the composites of HT18's 0.1 percentile-extreme. This indicates that the 2018 case is an extreme event among extreme rainfall events, and the 2017 case is an extreme event among extreme convection events.

The similarities between the two cases and HT18's results indicate that extreme rainfall can occur repeatedly under similar environmental conditions, which is informative for prediction and disaster prevention. A similar relationship between a case study and a statistical study is confirmed between a case study by Hirota et al. (2016), which demonstrated an interplay of an upper tropospheric cut-off low and an atmospheric river to enhance precipitation in Hiroshima on 19 August 2014, and Tsuji and Takayabu (2019), which statistically investigated precipitation enhancement related to cut-off lows and atmospheric rivers.

Recent studies reveal the importance of upper tropospheric phenomena on rainfall events over Japan (e.g., Horinouchi 2014; Hirota et al. 2016; Tsuji and Takayabu 2019; Yokoyama et al. 2020). Similar points are emphasized by studies about rainfall events in other regions. For example, Hardy et al. (2017) showed precipitation sensitivity to upper tropospheric PV anomalies in the United Kingdom. de Vries et al. (2018) demonstrated the importance of an interaction between upper tropospheric PV feature and integrated water vapor transport for a rainfall event that occurred in the Middle East region. Our results emphasize the importance to pay an attention to upper tropospheric phenomena when analyzing rainfall events around Japan.

\section{Acknowledgments}

The authors are sincerely grateful to two anonymous reviewers and the Editor Prof. T. Takemi for critical reading of the original manuscript and providing useful comments. This study is supported by the University of Tokyo through a project, "Research hub for the big data analysis of global water cycle and precipitation in changing climate", the JSPS KAKENHI Grant (15H02132 and 18K19951), the Environment Research and Technology Development Fund (JPMEERF20192004) of the Environmental Restoration and Conservation Agency, and the 8th RA of the Japan Aerospace Exploration Agency (JAXA) Precipitation Measuring Mission science. The GSMaP data were produced and distributed by the Earth Observation Research Center, JAXA. The JRA55 data were provided by the JMA. The JMA upper air observation data for July 2018 were provided by way of "Meteorological Research Consortium", a framework for research cooperation of JMA and Meteorological Society of Japan. The authors are also indebted to Prof. H. Niino at the University of Tokyo for his help in obtaining the JMA upper air observation data. The weather radar data were collected and distributed by Research Institute for Sustainable Humanosphere, Kyoto University (http://database.rish.kyoto-u.ac.jp/ index-e.html). The authors would like to thank Enago (www.enago.jp) for the English language review.

\section{References}

Akiyama, T., 1975: Southerly transversal moisture flux into the extremely heavy rainfall zone in the Baiu season. $J$. Meteor. Soc. Japan, 53, 304-316.

Aonashi, K., J. Awaka, M. Hirose, T. Kozu, T. Kubota, G. Liu, S. Shige, S., Kida, S. Seto, N. Takahashi, and Y. N. Takayabu, 2009: GSMaP passive, microwave precipitation retrieval algorithm: Algorithm description and validation. J. Meteor. Soc. Japan, 87A, 119-136.

de Vries, A. J., H. G. Ouwersloot, S. B. Feldstein, M. Riemer, A. M. El Kenawy, M. F. McCabe, and J. Lelieveld, 2018: Identification of tropical-extratropical interactions and extreme precipitation events in the Middle East based on potential vorticity and moisture transport. J. Geophys. Res. Atmos., 123, 861-881.

Hamada, A., and Y. N. Takayabu, 2018: Large-scale environmental conditions related to midsummer extreme rainfall events around Japan in the TRMM region. $J$. Climate, 31, 6933-6945.

Hamada, A., Y. N. Takayabu, C. Liu, and E. J. Zipser, 2015: Weak linkage between the heaviest rainfall and tallest storms. Nat. Commun., 6, 6213, doi:10.1038/ncomms 7213.

Harada, Y., H. Kamahori, C. Kobayashi, H. Endo, S. Kobayashi, Y. Ota, H. Onoda, K. Onogi, K. Miyaoka, and K. Takahashi, 2016: The JRA-55 Reanalysis: Representation of atmospheric circulation and climate variability. J. Meteor. Soc. Japan, 94, 269-302.

Hardy, S., D. M. Schultz, and G. Vaughan, 2017: The 23-26 September 2012 U. K. floods: Using PV surgery to quantify sensitivity to upper-level forcing. Mon. Wea. 
Rev., 145, 4055-4079.

Hirota, N., Y. N. Takayabu, M. Kato, and S. Arakane, 2016: Roles of an atmospheric river and a cutoff low in the extreme precipitation event in Hiroshima on 19 August 2014. Mon. Wea. Rev., 144, 1145-1160.

Holton, J. R., 2004: An Introduction to Dynamic Meteorology. 4th Edition. Academic Press, 535 pp.

Holton, J. R., P. H. Haynes, M. E. McIntyre, A. R. Douglass, R. B. Hood, and L. Pfister, 1995: Stratospheretroposphere exchange. Rev. Geophys., 33, 403-439.

Horinouchi, T., 2014: Influence of upper tropospheric disturbances on the synoptic variability of precipitation and moisture transport over summertime East Asia and the northwestern Pacific. J. Meteor. Soc. Japan, 92, 519-541.

Horinouchi, T., and A. Hayashi, 2017: Meandering subtropical jet and precipitation over summertime East Asia and the northwestern Pacific. J. Atmos. Sci., 74, 12331247.

Hoskins, B. J., I. Draghici, and H. C. Davies, 1978: A new look at the $\omega$-equation. Quart. J. Roy. Meteor. Soc., 104, 31-38.

Hoskins, B. J., M. E. McIntyre, and A. W. Robertson, 1985: On the use and significance of isentropic potential vorticity maps. Quart. J. Roy. Meteor. Soc., 111, 877946.

Japan Meteorological Agency, 2017: Baiu zensen oyobi taifu dai 3 gou niyoru ooame to boufu (Heavy rain and stormy wind by Baiu front and Typhoon No. 3 from 30 June to 10 July 2017). 34 pp (in Japanese). [Available at https:/www.data.jma.go.jp/obd/stats/data/bosai/ report/2017/20170711/jyun_sokuji20170630-0710. pdf.]

Japan Meteorological Agency, 2018: Heisei 30 nen 7 gatsu gouu (Rainfall event of July 2017). 53 pp (in Japanese). [Available at https://www.data.jma.go.jp/obd/ stats/data/bosai/report/2018/20180713/jyun_sokuji 20180628-0708.pdf.]

Japan Meteorological Agency Observations Department, 2004: $1 \mathrm{~km}$ mesh zenkoku gousei radar GPV no teikyoutou ni tsuite (Data provision of nationwide composited radar grid point value with $1 \mathrm{~km}$ resolutions). Technical Information, No. 162, 28 pp (in Japanese). [Available at https://www.data.jma.go.jp/add/suishin/ jyouhou/pdf/162.pdf.]

Kamae, Y., W. Mei, S.-P. Xie, M. Naoi, and H. Ueda, 2017: Atmospheric rivers over the northwestern Pacific: Climatology and interannual variability. J. Climate, 30, 5605-5619.

Kato, R., K. Shimose, and S. Shimizu, 2018a: Predictability of precipitation caused by linear precipitation systems during the July 2017 Northern Kyushu Heavy Rainfall Event using a cloud-resolving numerical weather prediction model. J. Disaster Res., 13, 846-859.

Kato, R., S. Shimizu, K. Shimose, T. Maesaka, N. Sakurai, and Y. Shusse, 2018b: Prompt report of meteorologi- cal analysis on the July 2017 Northern Kyushu Heavy Rainfall. Natural Disaster Research Report of the National Research Institute for Earth Science and Disaster Resilience, No. 52, 7 pp. (in Japanese).

Kato, T., M. Yoshizaki, K. Bessho, T. Inoue, Y. Sato, and X-BAIU-01 observation group, 2003: Reason for the failure of the simulation of heavy rainfall during X-BAIU-01-Importance of a vertical profile of water vapor for numerical simulations. J. Meteor. Soc. Japan, 81, 993-1013.

Kawano, T., K. Suzuki, and R. Kawamura, 2018: Heisei 29 nen 7 gatsu gouu wo motarashita senjyoukousuitai no hatsuraitokusei (Lightning properties in line-shaped precipitation systems inducing the 2017 Northern Kyushu rainfall event). Proceeding of Meteorological Society of Japan Autumn Meeting, Sendai, Japan, Meteorological Society of Japan, A356 (in Japanese).

Kobayashi, S., Y. Ota, Y. Harada, A. Ebita, M. Moriya, H. Onoda, K. Onogi, H. Kamahori, C. Kobayashi, H. Endo, K. Miyaoka, and K. Takahashi, 2015: The JRA-55 Reanalysis: General specifications and basic characteristics. J. Meteor. Soc. Japan, 93, 5-48.

Kubota, T., S. Shige, H. Hashizume, K. Aonashi, N. Takahashi, S. Seto, M. Hirose, Y. N. Takayabu, K. Nakagawa, K. Iwanami, T. Ushio, M. Kachi, and K. Okamoto, 2007: Global precipitation map using satelliteborne microwave radiometers by the GSMaP project: Production and validation. IEEE Trans. Geosci. Remote Sens., 45, 2259-2275.

Martius, O., C. Schwierz, and M. Sprenger, 2008: Dynamical tropopause variability and potential vorticity streamers in the Northern Hemisphere-A climatological analysis. Adv. Atmos. Sci., 25, 367-380.

Moteki, Q., 2019: Role of Typhoon Prapiroon (Typhoon No. 7) on the formation process of the Baiu front inducing heavy rain in July 2018 in western Japan. SOLA, 15A, 37-42.

Mundhenk, B. D., E. A. Barnes, and E. D. Maloney, 2016: All-season climatology and variability of atmospheric rivers frequencies over the North Pacific. J. Climate, 29, 4885-4903.

Nagata, M., and Y. Ogura, 1991: A modeling case study of interaction between heavy precipitation and a lowlevel jet over Japan in the Baiu season. Mon. Wea. Rev., 119, 1309-1336.

Ninomiya, K., and K. Yamazaki, 1979: Heavy rainfalls associated with frontal depression in Asian subtropical humid region. (II) Mesoscale features of precipitation, radar echoes and stratification. J. Meteor. Soc. Japan, 57, 399-413.

Ninomiya, K., and T. Akiyama, 1992: Multi-scale features of Baiu, the summer monsoon over Japan and the East Asia. J. Meteor. Soc. Japan, 70, 467-495.

Ogura, Y., T. Asai, and K. Dohi, 1985: A case study of a heavy precipitation event along the Baiu front in northern Kyushu, 23 July 1982: Nagasaki heavy rain- 
fall. J. Meteor. Soc. Japan, 63, 883-900.

Sampe, T., and S.-P. Xie, 2010: Large-scale dynamics of the meiyu-baiu rainband: Environmental forcing by the westerly jet. J. Climate, 23, 113-134.

Sekizawa, S., T. Miyasaka, H. Nakamura, A. Shimpo, K. Takemura, and S. Maeda, 2019: Anomalous moisture transport and oceanic evaporation during a torrential rainfall event over western Japan in early July 2018. SOLA, 15A, 25-30.

Shimpo, A., K. Takemura, S. Wakamatsu, H. Togawa, Y. Mochizuki, M. Takekawa, S. Tanaka, K. Yamashita, S. Maeda, R. Kurora, H. Murai, N. Kitabatake, H. Tsuguti, H. Mukougawa, T. Iwasaki, R. Kawamura, M. Kimoto, I. Takayabu, Y. N. Takayabu, Y. Tanimoto, T. Hirooka, Y. Masumoto, M. Watanabe, K. Tsuboki, and H. Nakamura, 2019: Primary factors behind the Heavy Rainfall Event of July 2018 and the subsequent heat wave in Japan. SOLA, 15A, 13-18.

Takemi, T., 2018: Importance of terrain representation in simulating a stationary convective system for the July 2017 Northern Kyushu Heavy Rainfall case. SOLA, 14, 153-158.

Takemi, T., and T. Unuma, 2019: Diagnosing environmental properties of the July 2018 Heavy Rainfall event in Japan. SOLA, 15A, 60-65.

Takemura, K., S. Wakamatsu, H. Togawa, A. Shimpo, C. Kobayashi, S. Maeda, and H. Nakamura, 2019: Extreme moisture flux convergence over western Japan during the Heavy Rain Event of July 2018. SOLA, 15A, 49-54.
Tsuguti, H., and T. Kato, 2014: Contributing factors of the heavy rainfall event at Amami-Oshima Island, Japan, on 20 October 2010. J. Meteor. Soc. Japan, 92, 163183.

Tsuguti, H., N. Seino, H. Kawase, Y. Imada, T. Nakaegawa, and I. Takayabu, 2018: Meteorological overview and mesoscale characteristics of the Heavy Rain Event of July 2018 in Japan. Landslides, 16, 363-371.

Tsuji, H., and Y. N. Takayabu, 2019: Precipitation enhancement via the interplay between atmospheric rivers and cutoff lows. Mon. Wea. Rev., 147, 2451-2466.

Unuma, T., and T. Takemi, 2016: Characteristics and environmental conditions of quasi-stationary convective clusters during the warm season in Japan. Quart. J. Roy. Meteor. Soc., 142, 1232-1249.

Yatagai, A., K. Minami, M. Masuda, and N. Sueto, 2019: Development of intensive APHRODITE hourly precipitation data for assessment of the moisture transport that caused heavy precipitation events. SOLA, 15A, 43-48.

Yokoyama, C., Y. N. Takayabu, and T. Horinouchi, 2017: Precipitation characteristics over East Asia in early summer: Effects of the subtropical jet and lowertropospheric convective instability. J. Climate, 30, 8127-8147.

Yokoyama, C., H. Tsuji, and Y. N. Takayabu, 2020: The effects of an upper-tropospheric trough on the heavy rainfall event in July 2018 over Japan. J. Meteor. Soc. Japan, 98, 235-255. 